\title{
High-altitude dynamics of snow load values on the Mount Elbrus slopes
}

\author{
Anatoly Adzhiev ${ }^{*}$, Mukhtar Bekkiev, Natalia Kondratieva, Natalia Yurchenko, and Leila \\ Kubadieva \\ High Mountain Geophysical Institute, 360030, Nalchik, Russia
}

\begin{abstract}
The study results of the snow load values' high-altitude dynamics, the snow cover weight value and its change with height for the designed objects of all-season tourist and recreational complex "Elbrus" at the altitudes from $2000 \mathrm{~m}$ to $3840.6 \mathrm{~m}$ are presented. Monthly measurements of the snow cover height have been carried out at various heights for this purpose. Based on the results of the snow cover height and density obtained values, a linear regression model of water content dependence in the snow cover on the height above sea level has been built. The main calculation method for finding the linear equation coefficients is the least squares technique. The calculated values of the snow cover weight on $1 \mathrm{~m}^{2}$ earth surface of different coverage have been obtained. Its value at an altitude of $3500 \mathrm{~m}$ above sea level is $10,42 \mathrm{kPa}$ at $2 \%$ coverage and $11.16 \mathrm{kPa}$ at $1 \%$ coverage.
\end{abstract}

\section{Introduction}

The snow load on buildings and structures is created by the snow cover weight, the value of which is $\mathrm{kgf} / \mathrm{m}^{2}$ numerically equal to water stock in millimeters. A serious risk may be associated with the snow cover load $[1,2]$. The exact parameters of the snow load are recorded in Code of Specification by the regions of Russia [3]. The snow load on the roof is formed under the influence of a number of additional factors, the mutual relationship and the calculated load of the snow cover during the design of various objects is calculated from the normative by multiplying the normative load by the coefficient $(\mu)$ transition from the weight of the ground snow cover to the snow load on the cover, which changes in accordance with the application $B$ Code of Specification 20.13330.2016. Standard value of the snow cover weight $S g$ on $1 \mathrm{~m}^{2}$ horizontal earth surface is taken depending on the snow region for the territory of the Russian Federation. However, the values obtained in this case are in many cases significantly overestimated, and underestimated in poorly studied areas. These territories include the All-Russian all-season tourist and recreational complex «Elbrus», created on the southern slope of Elbrus. The projected facilities of the all-season tourist and recreational complex "Elbrus" are located at the altitudes from $2100 \mathrm{~m}$ to $6045 \mathrm{~m}$. According to the zoning plan of the Russian Federation by snow load (Code of Specification 20.13330.2016, attachment $E$ ) the all-season tourist and recreational complex «Elbrus» is

\footnotetext{
* Corresponding author: adessa1@yandex.ru
} 
located in zone II and according to Table 10.1 of the above-mentioned Code of Specification, the standard value of the snow cover weight $(S g)$ is $1 \mathrm{kPa}$.

According to the part 10.2 Code of Specification 20.13330.2011, included in the List of national standards and sets of rules (parts of the standards and sets of rules), as a result of which the compliance with the requirements of the Federal Law of the Russian Federation "Technical Regulations on the Safety of Buildings and Structures" dated 30.12.2009, No. 384-Federal Law, in mountainous and poorly studied areas indicated on map 1 of Appendix $\mathrm{G}$, at the points with an altitude of more than $1500 \mathrm{~m}$, in the places with difficult terrain and in other cases, the weight of the snow cover may be determined in the prescribed manner based on the data from the nearest meteorological stations of Roshydromet on a mandatory basis. In this case, the value of the snow cover weight should be taken as the annual maximum weight of the snow cover, which is exceeded, on average, once every 25 years, determined on the route snow surveys data basis on the water reserves in the areas protected from direct wind impact (in the forest under the crowns of trees or in forest glades) for a period of at least 20 years.

The purpose of this study is to determine the standard value of the snow cover weight and changes in its values with a height from $2000 \mathrm{~m}$ to $3840.6 \mathrm{~m}$ in the territory of all-season tourist and recreational complex «Elbrus». The series of annual maximums of the water reserve in the snow cover, obtained as a result of snow route observations in the territory of all-season tourist and recreational complex «Elbrus», were used.

\section{The main objectives of the study:}

- analysis of the snow-cover height distribution on the territory all-season tourist and recreational complex «Elbrus» at the heights from $2800 \mathrm{~m}$ to $3840.6 \mathrm{~m}$;

- the snow cover weight normative value determination and changes with the height of the terrain, the weight of the snow for the projected objects of all-season tourist and recreational complex «Elbrus» at the heights from $2800 \mathrm{~m}$ to $3840.6 \mathrm{~m}$;

- comparison of the obtained calculated values of the snow cover weight and changes with the terrain height with their normative values according to Code of Specification 20.13330.2016.

\section{Materials and Methods}

Monthly monitoring of the snow cover height was carried out at 11 stationary points on the territory of all-season tourist and recreational complex "Elbrus", as well as on the territory of Polyana Azau (Moscow State University recreation area). 11 snow stakes have been installed for this. The location of the snow stakes is presented in Table 1. The altitude range of the snow stakes locations was from $2300 \mathrm{~m}$ to $3840,6 \mathrm{~m}$. The height difference was about 1540 $\mathrm{m}$.

Table 1. Locations of snow stakes across the territory of all-season tourist and recreational complex «Elbrus».

\begin{tabular}{|c|c|c|c|c|}
\hline \multirow{2}{*}{$\begin{array}{c}\text { Snow } \\
\text { stake No. }\end{array}$} & \multicolumn{3}{|c|}{ Coordinates } & \multirow{2}{*}{$\begin{array}{c}\text { Observation } \\
\text { point No. }\end{array}$} \\
\cline { 2 - 4 } & Latitude North & Longitude East & Height & \\
\hline 1 & $43^{\circ} 17^{\prime} 23^{\prime \prime}$ & $42^{\circ} 27^{\prime} 43^{\prime \prime}$ & 3461.6 & 1 \\
\hline 2 & $43^{\circ} 18^{\prime} 14^{\prime \prime}$ & $42^{\circ} 27^{\prime} 38^{\prime \prime}$ & 3840.6 & 2 \\
\hline 3 & $43^{\circ} 17^{\prime} 58^{\prime \prime}$ & $42^{\circ} 27^{\prime} 51^{\prime \prime}$ & 3704.4 & 3 \\
\hline 4 & $43^{\circ} 17^{\prime} 44^{\prime \prime}$ & $42^{\circ} 27^{\prime} 46^{\prime \prime}$ & 3571.6 & 4 \\
\hline 5 & $43^{\circ} 17^{\prime} 25^{\prime \prime}$ & $42^{\circ} 27^{\prime} 24^{\prime \prime}$ & 3347.9 & 5 \\
\hline 6 & $43^{\circ} 16^{\prime} 57^{\prime \prime}$ & $42^{\circ} 27^{\prime} 39^{\prime \prime}$ & 3136.5 & 6 \\
\hline 7 & $43^{\circ} 16^{\prime} 40^{\prime \prime}$ & $42^{\circ} 27^{\prime} 38^{\prime \prime}$ & 3020.3 & 7 \\
\hline
\end{tabular}




\begin{tabular}{|c|c|c|c|c|}
\hline 8 & $43^{\circ} 16^{\prime} 29^{\prime \prime}$ & $42^{\circ} 27^{\prime} 51^{\prime \prime}$ & 2869.6 & 8 \\
\hline 9 & $43^{\circ} 16^{\prime} 04^{\prime \prime}$ & $42^{\circ} 28^{\prime} 04^{\prime \prime}$ & 2727.3 & 9 \\
\hline 10 & $43^{\circ} 16^{\prime} 02^{\prime \prime}$ & $42^{\circ} 28^{\prime} 25^{\prime \prime}$ & 2484.1 & 11 \\
\hline 11 & \multicolumn{2}{|r|}{$\begin{array}{c}\text { on the Polyana Azau territory of } \\
\text { the Moscow State University } \\
\text { recreation area }\end{array}$} & 2300 & \\
& \multicolumn{2}{r}{$42^{\circ} 28^{\prime} 49^{\prime \prime}$} & & \\
& $43^{\circ} 15^{\prime} 59^{\prime \prime}$ & & \\
\hline
\end{tabular}

In addition, data from the nearest weather stations were used to analyze the characteristics of the snow cover in the study area «Terskol», «Cheget» and «Terskol Peak».

Seasonal dynamics of the snow cover height in different periods of the year is shown in Figure $1(\mathrm{a}, \mathrm{b}, \mathrm{c})$. As it can be seen from Figure 1c, on the territory of all-season tourist and recreational complex «Elbrus» the maximum snow cover height $-251 \mathrm{~cm}$ is observed in the month of May at an altitude of $3461.6 \mathrm{~m}$ above sea level.

To build the models of relationships between snow cover height and height above sea level, we have selected the exponential functions of the form:

$$
F=a X^{n}+b
$$

In Figure $1(\mathrm{a}, \mathrm{b}, \mathrm{c})$, thin solid lines are the approximating lines of the dependence of $\mathrm{h}$ (cm) on $H(\mathrm{~m})$, realized by the expressions of the form (1).

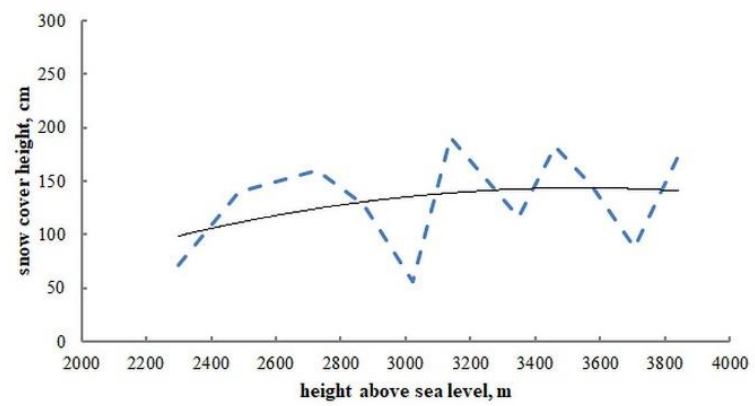

a)

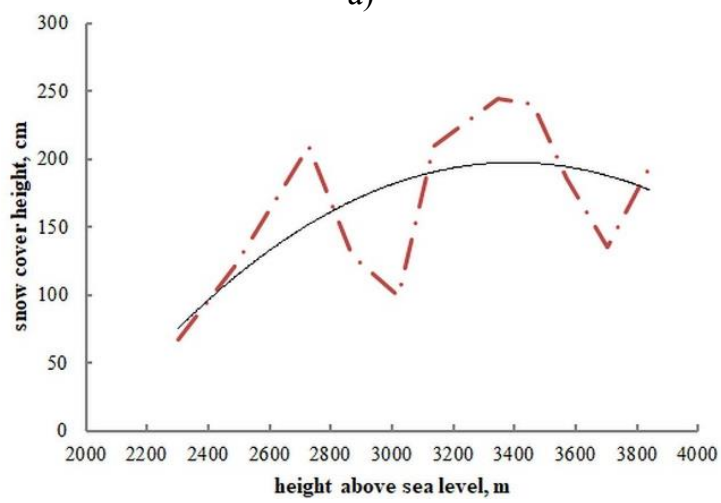

b) 


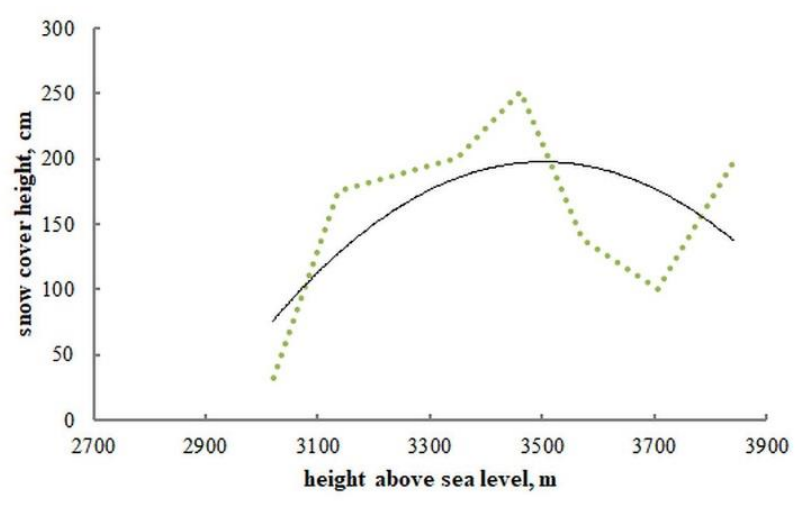

c)

Fig. 1. Seasonal dynamics of the snow cover height at different heights in the territory of all-season tourist and recreational complex «Elbrus»: a) in January; b) in April; c) in May.

Based on the studies carried out, the following conclusions on the snow accumulation dynamics in the territory of all-season tourist and recreational complex «Elbrus» can be drawn:

- The greatest snow accumulation in the territory of all-season tourist and recreational complex «Elbrus» is observed from March to May.

- There is high-altitude zoning in snow thickness growth dynamics. A rapid increase in the height of the snow cover is observed at the altitudes $3700 \div 3800 \mathrm{~m}$, near the station «GaraBashi».

- In the territory of all-season tourist and recreational complex «Elbrus» wind redistribution of snow is observed. So, the snow thickness in January 2019 between the station «Gara-Bashi» and the sports base "Bochki" is $220 \mathrm{~cm}$ at an altitude of $3704.4 \mathrm{~m}$. Here the snow thickness is about $50 \mathrm{~cm}$ greater than the snow thickness near the station «GaraBashi», height $3840.6 \mathrm{~m}$.

- For the first time snow cover on the territory of all-season tourist and recreational complex appears at an altitude of $3500 \mathrm{~m}$ in early October and only after $25 \div 30$ days snow cover forms at an altitude of $2500 \mathrm{~m}$.

- Snow accumulation rate on the territory of all-season tourist and recreational complex for the period from October 1 to March 31, 2019 at various altitudes ranged from $1.2 \mathrm{~cm}$ per day at an altitude of $2500 \mathrm{~m}$ and up to $2 \mathrm{~cm}$ per day at an altitude of $3840.6 \mathrm{~m}$.

- The decrease in the height of the snow cover begins in April. A rapid decrease in snow cover height occurs at heights $2484 \div 3347 \mathrm{~m}$, slower at altitudes $3700 \div 3800 \mathrm{~m}$, near the station «Gara-Bashi».

- For the first time snow cover on the territory all-season tourist and recreational complex descends at an altitude of $2484 \mathrm{~m}$ (Azau river) in early May and only after $25 \div 30$ days the snow cover melts at an altitude of $3000 \mathrm{~m}$.

- The decrease rate in the snow thickness on the territory of all-season tourist and recreational complex "Elbrus" for the period from April 1 to June 31, 2019 at various altitudes ranged from $8.2 \mathrm{~cm}$ per day at an altitude of $2500 \mathrm{~m}$ to $4.5 \mathrm{~cm}$ per day at an altitude of $3840.6 \mathrm{~m}$. 


\section{Results obtained and their discussion}

From the values of the snow cover height and the snow density, water reserve in the snow cover can be calculated that is, the height of the water layer that is formed during snow melting $[4,5]$. It is calculated by the formula:

$$
W=10 h
$$

where

$W$ is water content in $\mathrm{mm}$;

$h$ is snow cover thickness in $\mathrm{cm}$,

$\rho$ is snow cover density in $\mathrm{g} / \mathrm{cm}^{3}$;

10 is a multiplier for converting centimeters to millimeters.

The snow cover density measurements are made at weather stations. Along with the density determination, microclimatic observations are also carried out on the snow surface at an altitude $1.5 \div 2 \mathrm{~m}$. For this purpose, the following values are measured: air temperature, temperature on the snow surface and inside the snow mass.

Average snow cover density varies widely: dry snow $10 \div 20 \mathrm{~kg} / \mathrm{m}^{3}$, damp snow $100 \div 300$ $\mathrm{kg} / \mathrm{m}^{3}$, settled snow $200 \div 600 \mathrm{~kg} / \mathrm{m}^{3}$, old snow $300 \div 700 \mathrm{~kg} / \mathrm{m}^{3}$. A large number of works are devoted to the study of the changes' regularities in the snow cover density in the Caucasus mountains. The most significant of these studies are $[5,6]$. The integrated materials of M.Ch. Zalikhanov [6], indicate that the most typical for most of the all-season tourist and recreational complex «Elbrus» territory are the order values $0.3 \div 0.4 \mathrm{~g} / \mathrm{cm}^{3}$.

The expression to determine the snow density value at an altitude of $\mathrm{H}(\mathrm{m})$ in the territory of all-season tourist and recreational complex «Elbrus» is obtained in this work, by the interpolation method:

$$
\rho(\mathrm{H})=\rho_{1}+\frac{\left(\rho_{2}-\rho_{1}\right)\left(\mathrm{H}-\mathrm{H}_{1}\right)}{\left(\mathrm{H}_{2}-\mathrm{H}_{1}\right)}
$$

where

$\rho_{1}, \rho_{2}$ denote snow density values at the stations «Terskol» and «Terskol Peak»,

$H_{l}$ and $H_{2}$ are the station heights «Terskol» and «Terskol Peak».

The values of the snow cover height and information on their water equivalent, taking into account the snow density from the expression (3), according to long-term observations with the highest snow cover in late April - early May, according to the performed snow measurements for different heights are presented in Table 2.

Table 2. Estimated characteristics of snow cover for different heights in the territory of all-season tourist and recreational complex «Elbrus».

\begin{tabular}{|c|c|c|c|c|c|}
\hline $\mathrm{H}$, height & $\rho, \mathrm{g} / \mathrm{cm}^{3}$ & $\mathrm{~h}_{2 \%}, \mathrm{~cm}$ & $\mathrm{~W}_{2 \%}, \mathrm{~mm}$ & $\mathrm{~h}_{1 \%}, \mathrm{~cm}$ & $\mathrm{~W}_{1 \%}, \mathrm{~mm}$ \\
\hline 2150 & 0.360 & 105 & 378 & 115 & 414 \\
\hline 2300 & 0.361 & 124 & 448 & 136 & 489 \\
\hline 2500 & 0.363 & 150 & 544 & 163 & 592 \\
\hline 2600 & 0.364 & 163 & 593 & 176 & 643 \\
\hline 2700 & 0.365 & 176 & 642 & 190 & 695 \\
\hline 2800 & 0.366 & 189 & 692 & 204 & 747 \\
\hline 2900 & 0.367 & 202 & 741 & 218 & 799 \\
\hline 3000 & 0.368 & 215 & 791 & 231 & 852 \\
\hline 3100 & 0.369 & 228 & 841 & 245 & 905 \\
\hline 3150 & 0.370 & 235 & 869 & 252 & 932 \\
\hline 3500 & 0.372 & 280 & 1042 & 300 & 1116 \\
\hline
\end{tabular}


The values of $h$ given in Table 2 correspond to a snow cover height of $2 \%$ of coverage. Their values were obtained from long-term observations at the stations «Terskol» (height $2150 \mathrm{~m}$ ), «Terskol Peak» height $3150 \mathrm{~m}$ ) and the occasional observations of FSBI "High Mountain Geophysical Institute". The following expression has been received to obtain the height distribution of $h$ value by the interpolation method:

$$
h_{2 \%}(H)=105+0,12963 \cdot(H-2150)
$$

where $h(H)$ is the value of snow cover height at the altitude $H, \mathrm{~m}$.

For $1 \%$ of the snow cover height, the expression is obtained:

$$
h_{1 \%}(H)=115+0,137(H-2150)
$$

The estimated values of $1 \%$ and $2 \%$ snow cover height for different heights in the territory of all-season tourist and recreational complex «Elbrus» and the corresponding values of water content are given in Table 2.

The annual, maximum possible at the end of winter, water content in the snow cover - the maximum water content - is an important climatic characteristic of the territory, knowledge of which is necessary for predicting the spring-summer runoff of rivers, floods and mudflows, calculating snow loads on structures and solving many other applied problems $[2,7]$. The maximum water content, see the expression (2), is expressed in ( $\mathrm{mm}$ ) water layer, and is also numerically equal to the mass of snow falling on $1 \mathrm{~m}^{2}$ earth surface $\left(\mathrm{kg} / \mathrm{m}^{2}\right)$. In this case, it represents the snow load on the structures. According to Code of Specification [3], the average of the water content annual maximum values $W(\mathrm{~mm})$ is used as a standard parameter of snow loads on structures. In this case, it is numerically equal to the snow load $S\left(\mathrm{~kg} / \mathrm{m}^{2}\right)$. According to this indicator, the zoning of the flat part of the former USSR territory was carried out (map of snow regions M 1:15,000,000) with the allocation of mountain territories as unexplored, which includes the entire territory of all-season tourist and recreational complex «Elbrus» [3]. In what follows, we will use both terms, keeping in mind their complete equivalence.

An analytical expression for the height dependence $\mathrm{S}(\mathrm{mm})\left(\mathrm{kg} / \mathrm{m}^{2}\right) 1 \%$ and $2 \%$ of coverage is found, corresponding to Table 3 and the snow map [3] in the form:

$$
\begin{gathered}
S_{2 \%}=0,492 H-679,5 \\
S_{1 \%}=0,52 H-704,0
\end{gathered}
$$

It describes the entire territory of all-season tourist and recreational complex «Elbrus» and is universal, convenient for practical use of snow cover and snow loads water content distribution models on the southern slope of Elbrus. The table shows the range of heights within which the expressions (6) and (7) can be used.

Thus, it is clearly seen that the height is the determining factor for the snow loads formation. Only the simultaneous consideration of macro- and meso- relief conditions and the altitude of the site makes it possible to explain such a territorial distribution of $S$.

According to the application $E$ Code of Specification 20.13330.2016 the territory of allseason tourist and recreational complex «Elbrus» objects refers to region II (mountainous, poorly explored region). For mountainous regions, an expression for the snow load is proposed (Code of Specification 20.13330.2016, attachment $E$ ) depending on the height in the form:

$$
\mathrm{S}_{\mathrm{g}}(h)=S_{g}+k_{h}(h-500)
$$

where $k_{h}$ is an altitude coefficient of change in snow load, taken according to the table $E$ Code of Specification 20.13330.2016. $S_{g}=1.0 \mathrm{kPa}$.

The value $k_{h}$ for the KBR mountainous part, including for the territory of all-season tourist 
and recreational complex «Elbrus» in the above-mentioned Code of Specification is undefined. For comparative calculations, we took its value for the nearby territory, equal to $0.001 \mathrm{kPa} / \mathrm{m}$.

Table 3 shows the values of the snow cover weight on $1 \mathrm{~m}^{2}$ earth surface according to our proposed equations (6) and (7) and the standard weight of the snow cover on $1 \mathrm{~m}^{2}$ horizontal surface of the earth $S g$, $\mathrm{kPa}$ by Code of Specification 20.13330.2016, the equation (8).

As it can be seen from Table 3, in the values of the snow cover weight on $1 \mathrm{~m}^{2}$ obtained in this work and in the calculated values according to Code of Specification 20.13330.2016, there are significant differences of $21.6 \%$ at the altitudes of $2000 \mathrm{~m}$ and 2.6 times at the altitudes of $3500 \mathrm{~m}$ above sea level. Such a discrepancy in the values of the snow cover weight according to the data of meteorological stations and snow measuring surveys obtained in this work and according to Code of Specification due to coefficient $k_{h}$ incorrect value in Code of Specification for a given territory. The difference in the values of the snow cover weight by $1 \mathrm{~m}^{2}$ according to our data and the data calculated according to Code of Specification 20.13330.2016, is possibly also caused by the assumed value of the initial snow load $S g$ in the formula (8). Altitude coefficient of change $S_{g}$ at the altitudes of $2000 \mathrm{~m}$ is $0.00102 \mathrm{kPa} / \mathrm{m}$, and at an altitude of $3500 \mathrm{~m}$ it is $0,00269 \mathrm{kPa} / \mathrm{m}$. Similar conclusions were made in a number of works devoted to the snow load $[4,8]$.

Table 3. Values of the snow cover weight on $1 \mathrm{~m}^{2}$ earth surface according to the equations (6) and (7) and the standard weight of the snow cover on $1 \mathrm{~m}^{2}$ horizontal surface of the earth $S_{g}$, kPa by Code of Specification 20.13330.2016.

\begin{tabular}{|c|c|c|c|}
\hline Height, m & \multicolumn{2}{|c|}{$\begin{array}{c}\text { Snow cover weights per } 1 \mathrm{~m}^{2}, \mathrm{kPa} \\
\text { by the expressions (6) and (7) }\end{array}$} & $\begin{array}{c}S_{g}, \mathrm{kPa} \\
\text { by Code of } \\
\text { Specification } \\
20.13330 .2016, \\
\text { expression (8) }\end{array}$ \\
\hline 2000 & 3.04 & $1 \%$ coverage & 2.5 \\
\hline 2100 & 3.54 & 3.36 & 2.6 \\
\hline 2200 & 4.03 & 3.88 & 2.7 \\
\hline 2300 & 4.52 & 4.40 & 2.8 \\
\hline 2400 & 5.01 & 4.92 & 2.9 \\
\hline 2500 & 5.50 & 5.44 & 3.0 \\
\hline 2600 & 6.00 & 5.96 & 3.1 \\
\hline 2700 & 6.49 & 6.48 & 3.2 \\
\hline 2800 & 6.98 & 7.00 & 3.3 \\
\hline 2900 & 7.47 & 7.52 & 3.4 \\
\hline 3000 & 7.97 & 8.04 & 3.6 \\
\hline 3100 & 8.46 & 8.56 & 3.7 \\
\hline 3200 & 8.95 & 9.08 & 3.8 \\
\hline 3300 & 9.44 & 9.60 & 3.9 \\
\hline 3400 & 9.93 & 10.12 & 4.0 \\
\hline 3500 & 10.42 & 10.64 & 4.0 \\
\hline $3500-4500$ & 10.42 & 11.16 & \\
\hline & & 11.16 & \\
\hline
\end{tabular}

\section{Conclusion}

Scientific research has been carried out to determine the calculated values of the snow cover weight and the values of the altitude coefficient for the construction area of the all-season 
tourist and recreational complex «Elbrus» facility.

A regression linear model of the water content dependence in the snow cover $(\mathrm{mm})$ on the height above sea level $(\mathrm{m})$, in the form of a linear and exponential dependence.

From the obtained equations (6) and (7) it follows that with an increase in the height above sea level by $1 \mathrm{~m}$, the water content in the snow cover increases by $0.492 \mathrm{~mm}$ and by $0.52 \mathrm{~mm}$ at $2 \%$ and $1 \%$ coverage, respectively.

The calculated values of the snow cover weight on $1 \mathrm{~m}^{2}$ earth surface of various coverage. Its value at an altitude of $3500 \mathrm{~m}$ above sea level is $10.42 \mathrm{kPa}$ at $2 \%$ coverage and $11.16 \mathrm{kPa}$ at $1 \%$ coverage.

\section{References}

1. Guidelines for avalanche support of the national economy (Tashkent, 1987).

2. Yu.D. Moskalev, Avalanches and avalanche loads, SASRI works 109 (190), 156 (1986).

3. Code of Specification 20.13330.2016 Loads and impacts. Updated edition Construction Rules and Regulations 2.01.07-85*

4. I.A. Pavlova, O.A. Podrezov and A.O. Podrezov, Herald of KRSU 11 (11), 160-166 (2011).

5. Methodological recommendations for determining the snow cover regime characteristics in the mountains of Central Asia (Central Asian Regional Research Hydrometeorological Institute, Tashkent, 1988).

6. M.Ch. Zalihanov, Snow-avalanche regime and prospects for the development of the Greater Caucasus mountains. Monograph (Official and Business Russia, Moscow, 2014).

7. O.A. Podrezov, Mountain meteorology and climatology (Bishkek, 2000).

8. O.A. Podrezov, A.O. Podrezov, Herald of KRSU 11 (3), 53- 60 (2011). 